\title{
Health-related quality of life and coping strategies among people living with HIV: the moderating role of gender
}

\author{
Marcin Rzeszutek ${ }^{1}$
}

Received: 28 August 2017 / Accepted: 5 December 2017 / Published online: 18 December 2017

(C) The Author(s) 2017. This article is an open access publication

\begin{abstract}
The aim of the study was to explore gender differences in the level of health-related quality of life (HRQoL) and coping strategies among people living with the human immunodeficiency virus (HIV) (PLWH). In particular, the moderating role of participants' gender on the relationship between coping strategies and HRQoL was explored, while controlling for socio-medical data. A total of $444 \mathrm{HIV}$-infected men and $86 \mathrm{HIV}$-infected women were recruited to participate in the study. This was a cross-sectional study with the HRQoL assessed by the World Health Organization (WHO) Quality of Life-BREF (WHOQOL-BREF) and the coping strategies measured by the Brief COPE inventory. Although the HIV-infected men and HIV-infected women differed in terms of some HRQoL domains, these differences disappeared in the regression analysis after controlling for socio-demographic data (employment and higher education). In addition, several statistically significant interactions between participants' gender and coping strategies in relation to HRQoL domains were observed. Future research on gender differences in HRQoL among PLWH should take into account unique differences between HIV-infected men and HIV-infected women across, not only in respect to socio-medical factors but also regarding psychosocial variables.
\end{abstract}

Keywords HIV/AIDS $\cdot$ Health-related quality of life $\cdot$ Coping $\cdot$ Gender differences

Significant advances in the knowledge about and treatment of HIV infection has changed the nature of HIV/AIDS from a terminal disease to a chronic illness and has given people living with HIV (PLWH) new hope for increased life expectancy (Deeks et al. 2013; Samji et al. 2013). Nevertheless, PLWH still suffer from intense HIV-related distress, which stems not only from the awareness of a potentially lethal virus in their bodies, but also from the still existing stigma of HIV and the potential deterioration of their psychosocial status (Adewuya et al. 2009; Bogart et al. 2011; Machtinger et al. 2012; Pantalone et al. 2010; Rzeszutek et al. 2012, 2015). Therefore, apart from monitoring virological and immunological health outcomes, assessing subjective measures of health status, such as health-related quality of life (HRQoL), is becoming an integral part of medical examination among HIV/ AIDS health services (Bucciardini et al. 2014; Burgoyne and

Marcin Rzeszutek

marcin.rzeszutek@psych.uw.edu.pl

1 Faculty of Psychology, University of Warsaw, Stawki 5/7, 00-183 Warsaw, Poland
Saunders 2001; Herrmann et al. 2013; Mitchell et al. 2017; Ruiz-Perez et al. 2005). However, although numerous studies have been conducted on factors associated with HRQoL among PLWH (Miners et al. 2014), they have not provided a coherent picture of what factors enhance HRQoL in this patient group (Degroote et al. 2014).

One topic that deserves more attention deals with gender differences in HRQoL among PLWH, which especially applies to HIV-infected women (Carvalhal 2010). Although the number of HIV-infected women has been constantly increasing globally (UNAIDS Report 2017), considerably more research has been conducted among HRQoL in HIV-infected men (Emuren et al. 2017; Jia et al. 2004; Liu et al. 2006; Song et al. 2016), compared with HIV-infected women (e.g., Gielen et al. 2001; McDonnell et al. 2000). When it comes to gender differences in HRQoL among PLWH, the majority of existing studies show a rather consistent trend, i.e., a lower level of HRQoL among HIV-infected women compared to HIV-infected men (Campsmith et al. 2003; Chandra et al. 2009; Mrus et al. 2005; Solomon et al. 2008). It must be mentioned that some authors observed poorer HRQoL among HIV-infected men (Peltzer and Phaswana-Mafuya 2008) or no gender differences in respect to HRQoL in this patient group 
(Ruiz-Perez et al. 2009). Various explanations for the poorer HRQoL among HIV-infected women were suggested, including unequal access to antiretroviral treatment (ART) in some countries for HIV-infected women (Penniman et al. 2007), a higher rate of physical and emotional abuse and mental disorders among HIV-infected women (Machtinger et al. 2012), especially the heightened HIV-related stigma among HIVinfected women (Geary et al. 2014) which prevents them from disclosing their HIV+ status and seeking medical care (Campbell et al. 2006). However, other authors noticed significant gender differences in clinical outcomes, i.e., HIVinfected women reported higher CD4 count, lower viral load, and better adherence to treatment compared to HIV-infected men (Collazos et al. 2007; Nicastri et al. 2007). The nature of gender differences in HRQoL is complex, but, according to the newest studies, these differences may depend to a greater extent on socio-demographic or psychosocial factors rather than on the objective health status (Degroote et al. 2014; Vo et al. 2016).

One of these important psychosocial factors is coping with HIV infection (Gore-Felton et al. 2002; Vosvick et al. 2010). Although a significant number of studies were conducted on coping among PLWH (see, Moskowitz et al. 2009), several authors used different coping tools and relied on various coping classifications. This precludes obtaining an unambiguous picture of coping effectiveness among PLWH. Nevertheless, some agreement exists regarding three ways of coping: active coping, avoidance coping, and meaning-focused coping. Active coping appeared to be positively related not only to HIV-related clinical outcomes, but also to the enhancement of HRQoL among PLWH (Chida and Vedhara 2009; Ironson and Hayward 2008; Pence et al. 2008). Different forms of avoidance coping, including behavioral disengagement, substance use, and social isolation predicted consequent deterioration of health status, lower HRQoL, and lower adherence to treatment regimens (Griswold et al. 2005; Vervoort et al. 2009). Finally, meaning-focused coping appeared to be positively associated with affective well-being (Moskowitz et al. 2009, 2012). Regarding gender differences in coping with HIV infection, the results are mixed, ranging from studies that highlighted the lack of gender differences (Ashton et al. 2005; Gore-Felton et al. 2002) to research that pointed to a higher intensity of avoidance coping, spiritual coping, and seeking social support as coping strategies among HIV-infected women (Tarakeshwar et al. 2005; Vosvick et al. 2002). What remains especially unclear are gender differences in coping effectiveness, i.e., whether and how specific coping strategies may be related to selected aspects of physical, psychological, and social functioning separately among HIV-infected men and HIV-infected women.
Table 1 Socio-medical variables in the studied sample of HIVinfected men $(N=444)$ and HIVinfected women $(N=86)$

\begin{tabular}{|c|c|c|c|}
\hline Variable & $\begin{array}{l}\text { Male } \\
N(\%)\end{array}$ & $\begin{array}{l}\text { Female } \\
N(\%)\end{array}$ & $p$ \\
\hline Age in years $(\mathrm{M} \pm \mathrm{SD})$ & $39.75 \pm 10.54$ & $40.09 \pm 10.60$ & $t(528)=-.27, p>.05$ \\
\hline \multicolumn{4}{|l|}{ Marital status } \\
\hline Married & $245(55.2 \%)$ & $58(67.4 \%)$ & \multirow[t]{2}{*}{$\chi^{2}(1)=4.42 . p<.05$} \\
\hline Single & $199(44.8 \%)$ & $28(32.6 \%)$ & \\
\hline \multicolumn{4}{|l|}{ Education } \\
\hline Elementary & $22(5.0 \%)$ & $18(20.9 \%)$ & \multirow[t]{4}{*}{$\chi^{2}(3)=32.76 . p<.001$} \\
\hline Occupational & $38(8.6 \%)$ & $6(7.0 \%)$ & \\
\hline Secondary & $130(29.3 \%)$ & $32(37.2 \%)$ & \\
\hline University degree & $254(57.2 \%)$ & $30(34.9 \%)$ & \\
\hline \multicolumn{4}{|l|}{ Employment } \\
\hline Full employment & $339(76.4 \%)$ & $45(52.3 \%)$ & \multirow[t]{4}{*}{$\chi^{2}(3)=3.71 \cdot p<.001$} \\
\hline Unemployment & $42(9.5 \%)$ & $19(22.1 \%)$ & \\
\hline Retirement & $20(4.5 \%)$ & $1(1.2 \%)$ & \\
\hline Sickness allowance & $43(9.7 \%)$ & $21(24.4 \%)$ & \\
\hline \multicolumn{4}{|l|}{ HIV/AIDS status } \\
\hline HIV+ only & $375(84.5 \%)$ & $73(84.9 \%)$ & \multirow[t]{2}{*}{$\chi^{2}(1)=.01 . p>.05$} \\
\hline HIV/AIDS & $69(15.5 \%)$ & $13(15.1 \%)$ & \\
\hline $\begin{array}{l}\text { HIV infection duration in } \\
\text { years }(M \pm S D)\end{array}$ & $7.17 \pm 6.48$ & $10.86 \pm 7.88$ & $t(528)=-4.08, p<.001$ \\
\hline $\begin{array}{l}\text { Antiretroviral treatment }(\mathrm{ART}) \\
\text { duration in years }(\mathrm{M} \pm \mathrm{SD})\end{array}$ & $5.48 \pm 5.17$ & $8.53 \pm 6.57$ & $t(528)=-4.79, p<.001$ \\
\hline CD4 Count & $587.87 \pm 223.13$ & $597.64 \pm 219.79$ & $t(528)=-.37, p>.05$ \\
\hline
\end{tabular}

$M$, mean; $S D$, standard deviation; $t$, value of independent samples $t$ test; $\chi^{2}$, Pearson's Chi-squared test; $p$, statistical significance 


\section{Current study}

The aim of the current study was to explore gender differences in the level of HRQoL and coping strategies among people living with HIV. In particular, the moderating role of participants' gender on the relationship between coping strategies and HRQoL was explored, while controlling for sociomedical data. Based on the literature review, one direct and one indirect hypothesis were formulated; however, in this last hypothesis, an exploratory approach has primarily been utilized due to the lack of studies on the aforementioned topic. Firstly, it was expected that HIV-infected women would score lower on particular dimensions of HRQoL compared to HIVinfected men. Secondly, it was expected that the coping strategies would be differently related to particular HRQoL domains among HIV-infected women and HIV-infected men.

\section{Method}

\section{Participants}

A total of $444 \mathrm{HIV}$-infected men and $86 \mathrm{HIV}$-infected women were recruited from the patients of the outpatient clinic of the state hospital for infectious diseases. Participants completed a paper-and-pencil version of the two designated measures and participated voluntarily in the study; there was no remuneration. The eligibility criteria were that participants had to be 18 years of age or older, medically diagnosed as HIV-infected and receiving treatment from the hospital where the study was conducted. The exclusion criteria included HIV-related cognitive impairment diagnosed by medical doctors. This research project was also accepted by the local ethics committee. Socio-medical data characteristics among HIVinfected men and HIV-infected women are included in Table 1.

\section{Measures}

Health-related quality of life was assessed with the use of the World Health Organization (WHO) Quality of LifeBREF (WHOQOL-BREF), created by the WHO initiative to assess this construct cross-culturally (WHOQOL Group 1995) in a Polish adaptation. The WHOQOL-BREF consisted of 26 items to measure four domains: somatic health, psychological health, social relationships, and environment. Cronbach's alpha coefficients for the current study were satisfactory and exceeded .86 for the abovementioned HRQoL domains.

To measure strategies for coping with stress, the Brief COPE Inventory was used (Carver and Scheier 1997) in a
Table 2. Gender differences in health-related quality of life and of coping strategies.

\begin{tabular}{llllll}
\hline Variable & Male & Female & $t$ & df & $p$ \\
& $M(\mathrm{SD})$ & $M(\mathrm{SD})$ & & & \\
\hline WHO_somatic & $25.48(4.95)$ & $24.06(5.36)$ & 2.40 & 528 & .017 \\
WHO_psychological & $22.23(4.24)$ & $21.56(4.27)$ & 1.33 & 528 & .183 \\
WHO_social & $11.08(2.38)$ & $11.22(2.30)$ & -.49 & 528 & .621 \\
WHO_environmental & $30.46(5.29)$ & $28.50(5.65)$ & 3.11 & 528 & .002 \\
Active coping & $3.46(1.26)$ & $3.48(1.22)$ & -.10 & 528 & .919 \\
Planning & $3.60(1.34)$ & $3.59(1.35)$ & .05 & 528 & .958 \\
Positive reframing & $3.54(1.30)$ & $3.60(1.29)$ & -.45 & 528 & .654 \\
Acceptance & $3.95(1.20)$ & $3.81(1.13)$ & .97 & 528 & .330 \\
Humor & $2.87(1.42)$ & $2.64(1.34)$ & 1.39 & 528 & .166 \\
Religion & $2.40(1.90)$ & $2.41(1.76)$ & -.03 & 528 & .978 \\
Use of emotional support & $2.68(1.58)$ & $2.72(1.52)$ & -.21 & 528 & .835 \\
Use of instrumental support & $3.39(1.34)$ & $3.49(1.42)$ & -.63 & 528 & .527 \\
Self-distraction & $2.98(1.33)$ & $3.17(1.10)$ & -1.25 & 528 & .213 \\
Denial & $2.22(1.63)$ & $2.26(1.55)$ & -.20 & 528 & .845 \\
Venting & $2.93(1.41)$ & $2.97(1.49)$ & -.22 & 528 & .825 \\
Substance use & $2.25(1.84)$ & $1.83(1.71)$ & 1.97 & 528 & .050 \\
Behavioral disengagement & $2.35(1.62)$ & $2.21(1.61)$ & .76 & 528 & .448 \\
Self-blame & $2.88(1.58)$ & $2.67(1.54)$ & 1.10 & 528 & .272 \\
Rumination & $2.76(1.74)$ & $2.74(1.78)$ & .09 & 528 & .925 \\
Positive emotion enhancement & $3.91(1.36)$ & $3.86(1.38)$ & .28 & 528 & .779 \\
\hline
\end{tabular}

$M$, mean; $S D$, standard deviation; $t$, value of independent samples $t$ test; $d f$, degrees of freedom; $p$, statistical significance 
Polish adaptation. The questionnaire included 28 items and provided 14 subscales, two items each, with a Likert-like response scale ranging from 0 (I have not been doing this at all.) to 3 (I have been doing this a lot.). The aforementioned subscales were derived empirically, and they were not theoretically reassessed afterwards to obtain a more comprehensive systematization of coping strategies (Skinner et al. 2003). More specifically, as this tool does not contain items directly describing rumination, which is one of the most strongly proven maladaptive strategies (see NolenHoeksema et al. 2008) and items describing coping efforts to enhance positive emotions during stressful situations, these two items were added from the Ruminative
Response Styles (Treynor et al. 2003): I think "What am I doing to deserve this?"; I think "Why do I have problems other people don't have?") and from the Coping with Health Injuries and Problems Scale after modification (Endler et al. 1998): I have nice things around; I look for simple pleasures. Finally, 16 coping strategies were studied: self-distraction, active coping, denial, substance use, use of emotional support, use of instrumental support, behavioral disengagement, venting, positive reframing, planning, humor, acceptance, religion, self-blame, rumination, and positive emotion enhancement. The Cronbach's alpha coefficients for the current study were satisfactory and ranged from .78 to .86 for all subscales.

Table 3 Statistically significant interactions between participants' gender and coping strategies in relation to health-related qualify of life domains

\begin{tabular}{|c|c|c|c|c|c|c|c|c|c|c|c|}
\hline \multirow[t]{2}{*}{ Outcome } & \multirow[t]{2}{*}{ Predictors } & \multicolumn{4}{|c|}{ Total model } & \multicolumn{6}{|l|}{ Simple effects analysis } \\
\hline & & Beta & $t$ & $p$ & $\Delta R^{2}$ & Predictor & Moderator & Beta & $t$ & $p$ & $\Delta R^{2}$ \\
\hline \multirow[t]{4}{*}{ WHO_somatic } & Employment & .32 & 7.55 & .001 & 0.10 & \multirow{4}{*}{ Positive reframing } & & & & & \\
\hline & Gender & -.05 & -1.09 & .278 & 0.01 & & Male & .01 & .32 & .752 & 0.01 \\
\hline & Positive reframing & .14 & 2.43 & .016 & 0.01 & & Female & .24 & 2.36 & .020 & 0.06 \\
\hline & Positive reframing $\times$ gender & .12 & 2.19 & .029 & 0.01 & & & & & & \\
\hline \multirow[t]{4}{*}{ WHO_somatic } & Employment & .30 & 7.30 & .001 & 0.10 & \multirow{4}{*}{$\begin{array}{l}\text { Use of emotional } \\
\text { support }\end{array}$} & & & & & \\
\hline & Gender & -.04 & -1.07 & .283 & 0.01 & & Male & -.15 & -3.39 & .001 & .020 \\
\hline & Use of emotional support & .02 & .27 & .788 & 0.01 & & Female & .16 & 1.55 & .124 & .030 \\
\hline & Use of emotional support $\times$ gender & .16 & 2.88 & .004 & 0.01 & & & & & & \\
\hline \multirow{7}{*}{$\begin{array}{l}\mathrm{WHO}_{-} \\
\text {environmental }\end{array}$} & Employment & .26 & 5.75 & .000 & 0.08 & \multirow{7}{*}{ Positive reframing } & & & & & \\
\hline & Higher education & .17 & 3.98 & .001 & 0.03 & & & & & & \\
\hline & Age & .12 & 2.84 & .005 & 0.02 & & & & & & \\
\hline & $\mathrm{CD} 4$ & .09 & 2.28 & .023 & 0.01 & & & & & & \\
\hline & Gender & -.06 & -1.48 & .140 & 0.01 & & Male & -.03 & -.58 & .566 & .010 \\
\hline & Positive reframing & .11 & 1.92 & .050 & 0.01 & & Female & .26 & 2.58 & .012 & .070 \\
\hline & Positive reframing $\times$ gender & .13 & 2.41 & .016 & 0.01 & & & & & & \\
\hline \multirow[t]{7}{*}{ WHO_social } & Stable relationship & -.21 & -5.07 & .000 & 0.06 & \multirow{7}{*}{ Use of emotional support } & & & & & \\
\hline & Employment & .15 & 3.27 & .001 & 0.02 & & & & & & \\
\hline & AIDS & -.11 & -2.56 & .011 & 0.01 & & & & & & \\
\hline & Higher education & .09 & 1.96 & .050 & 0.01 & & & & & & \\
\hline & Gender & .04 & 1.03 & .303 & 0.01 & & Male & -.02 & -.43 & .671 & .010 \\
\hline & Use of emotional support & .13 & 2.18 & .030 & 0.01 & & Female & .29 & 2.77 & .007 & .080 \\
\hline & Use of emotional support $\times$ gender & .15 & 2.51 & .012 & 0.01 & & & & & & \\
\hline \multirow{7}{*}{$\begin{array}{l}\mathrm{WHO}_{\text {psychological }} \\
\end{array}$} & Employment & .26 & 5.79 & .000 & 0.06 & \multirow{7}{*}{$\begin{array}{c}\text { Positive emotion } \\
\text { enhancement }\end{array}$} & & & & & \\
\hline & CD4 & .14 & 3.50 & .001 & 0.02 & & & & & & \\
\hline & Stable relationship & -.11 & -2.68 & .008 & 0.01 & & & & & & \\
\hline & Age & .10 & 2.24 & .026 & 0.01 & & & & & & \\
\hline & Gender & -.02 & -.39 & .699 & 0.01 & & Male & .07 & 1.49 & .138 & .010 \\
\hline & Positive emotion enhancement & .25 & 4.61 & .000 & 0.02 & & Female & .40 & 3.81 & .001 & .140 \\
\hline & $\begin{array}{l}\text { Positive emotion enhancement } \times \\
\text { gender }\end{array}$ & .18 & 3.31 & .001 & 0.02 & & & & & & \\
\hline
\end{tabular}

Beta, standardized regression coefficients; $t$, test for significance of regression coefficient; $p$, statistical significance; $\Delta R^{2}$, change of determination coefficient 


\section{Data analysis}

The process of statistical analysis consisted of three steps. Firstly, the group of HIV-infected women and the group of HIV-infected men were compared in terms of socio-medical data. Secondly, these two groups were compared in terms of HRQoL and coping strategies. Thirdly, in order to verify if participants' gender moderates the relationship between coping strategies and HRQoL, regression analysis was performed. The statistical analysis was performed using the IBM SPSS Statistics 24 software released in 2016 (IBM Corp. Released 2016).

\section{Results}

Analyzed variables did not differ from the normal distribution, i.e., values of skewness for analyzed variables ranged from -.81 to .26 , and kurtosis values or analyzed variables ranged from -.71 to .76 . Table 2 presents gender differences in terms of HRQoL domains and coping strategies.

The main statistical method used was hierarchical regression analysis (Darlington and Hayes 2017). The first block was devoted to the selection using stepwise method of socio-medical variables that were significantly related to HRQoL domains, and, therefore, should be controlled. The second block added the main effects of gender and coping. The final block added the interaction between gender and coping. Table 3 presents results for the models with statistically significant interactions. Each interaction was followed by a simple effects analysis, which was performed separately in the groups of HIV-infected men and HIV-infected women.

None of the main of effects of gender was statistically significant, despite the statistically significant differences between means noticed in Table 2. HIV-infected men and HIVinfected women differed not only in terms of mean values of HRQoL but also in terms of socio-medical data which were significantly related to HRQoL domains. After inclusion of these data in the regression model, the effect of gender was statistically insignificant. There were no statistically significant differences in HRQoL domains that could be attributed directly to gender when gender differences regarding employment and higher education were taken into consideration.

There were five statistically significant interactions between participants' gender and coping strategies in relation to HRQoL domains. Positive reframing was positively related to the HRQoL somatic domain only in the group of HIVinfected women (Fig 1).

Use of emotional support was negatively related to the HRQoL somatic domain only in the group HIV-infected men (Fig 2).

Positive reframing was positively related to the HRQoL environmental domain only in the group of HIV-infected women (Fig. 3).

Use of emotional support was positively related to the HRQoL social domain only in the group of HIV-infected women (Fig. 4.).

Finally, positive emotion enhancement was positively related to the HRQoL psychological domain only in the group of HIV-infected women (Fig. 5).
Fig. 1 Relationship between positive reframing and somatic domain of health-related quality of life in the group of HIVinfected men and HIV-infected women

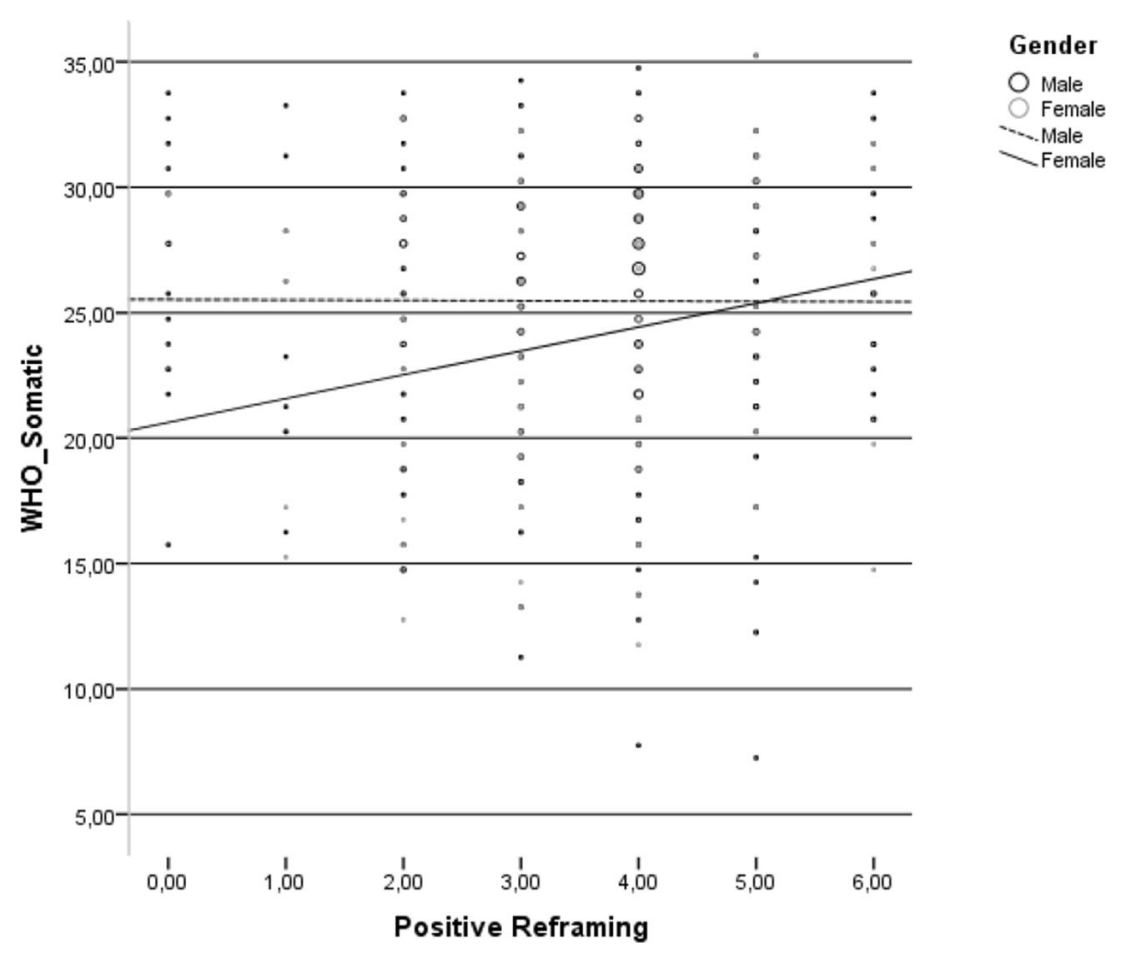


Fig. 2 Relationship between use of emotional support and somatic domain of health-related quality of life in the group of HIVinfected men and HIV-infected women

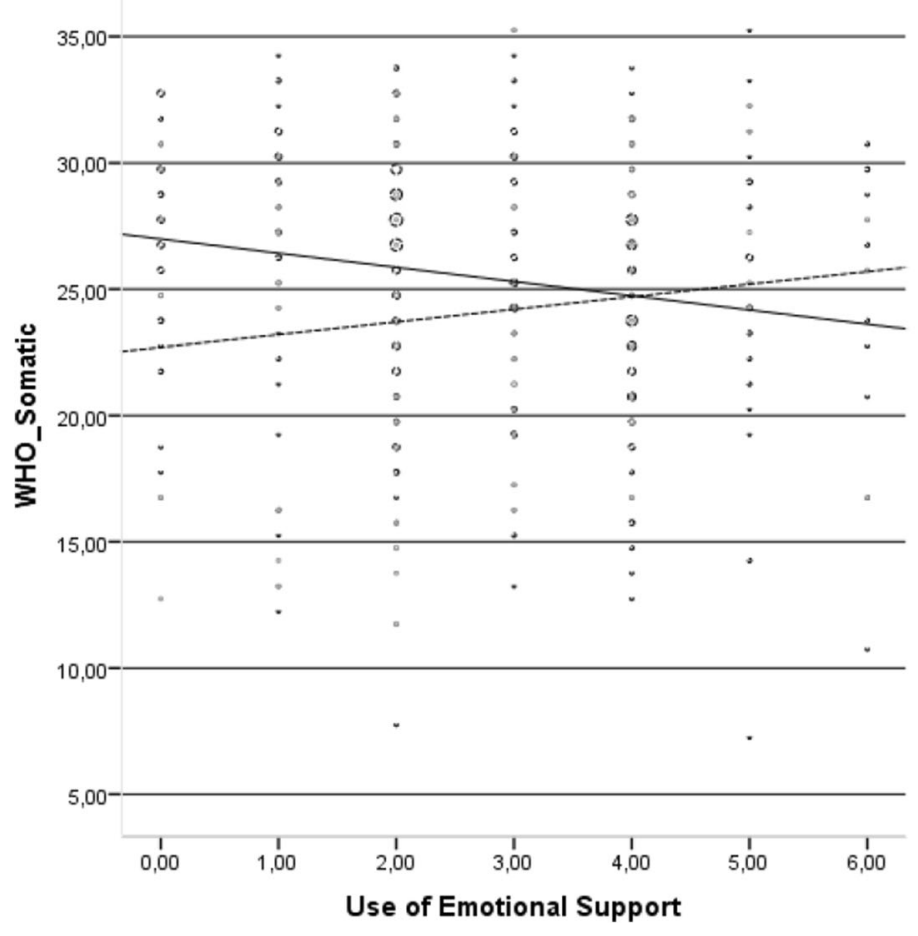

Gender

Male

Female Male -... Female

\section{Discussion}

The results of this study were somewhat inconsistent with the first hypothesis, i.e., although $\mathrm{HIV}$-infected women reported a lower level of particular HRQoL domains, these differences disappeared in the regression analysis after controlling for socio-demographic data (employment and higher education).
These findings contradict the aforementioned studies, which showed lower levels of HRQoL among HIV-infected women (Campsmith et al. 2003; Mrus et al. 2005; Solomon et al. 2008). However, Ruiz-Perez et al. (2009) also observed that the gender difference in HRQoL among PLWH disappeared after adjusting the results in terms of demographic and clinical data. In this study, the lower level of HRQoL in the somatic
Fig. 3 Relationship between positive reframing and environmental domain of healthrelated quality of life in the group of HIV-infected men and HIVinfected women

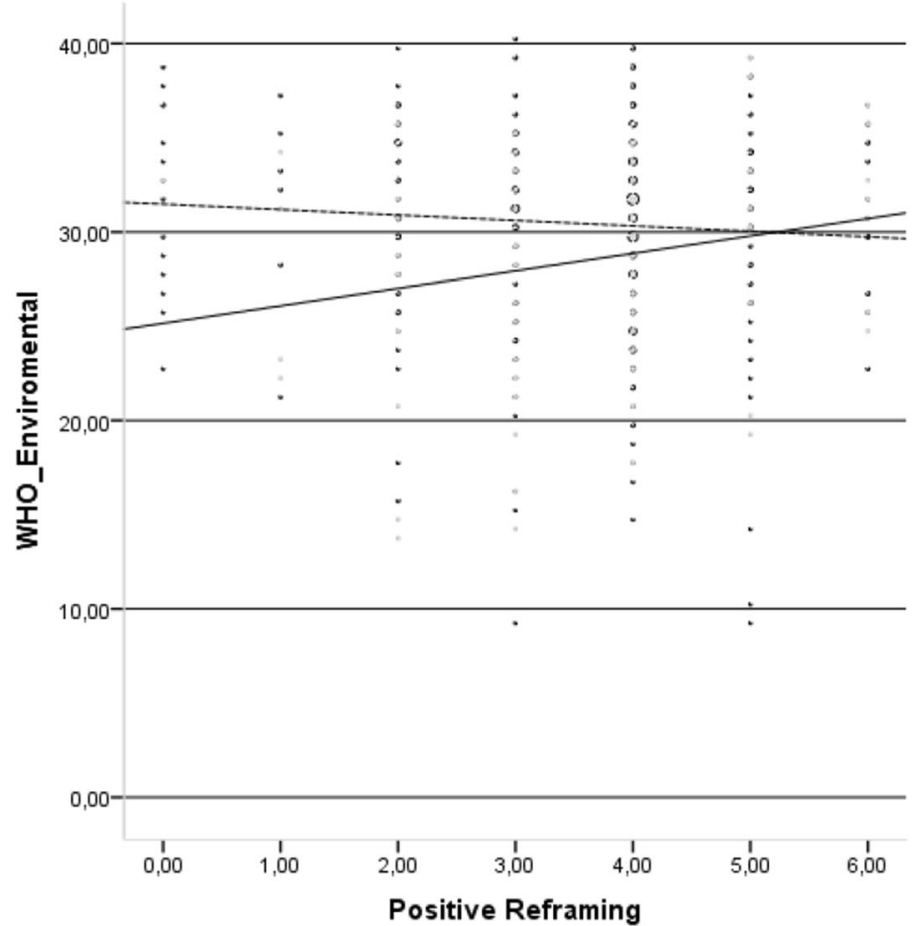

Gender () Male Female Male Female 
Fig. 4 Relationship between use of emotional support and social domain of health-related quality of life in the group of HIVinfected men and HIV-infected women

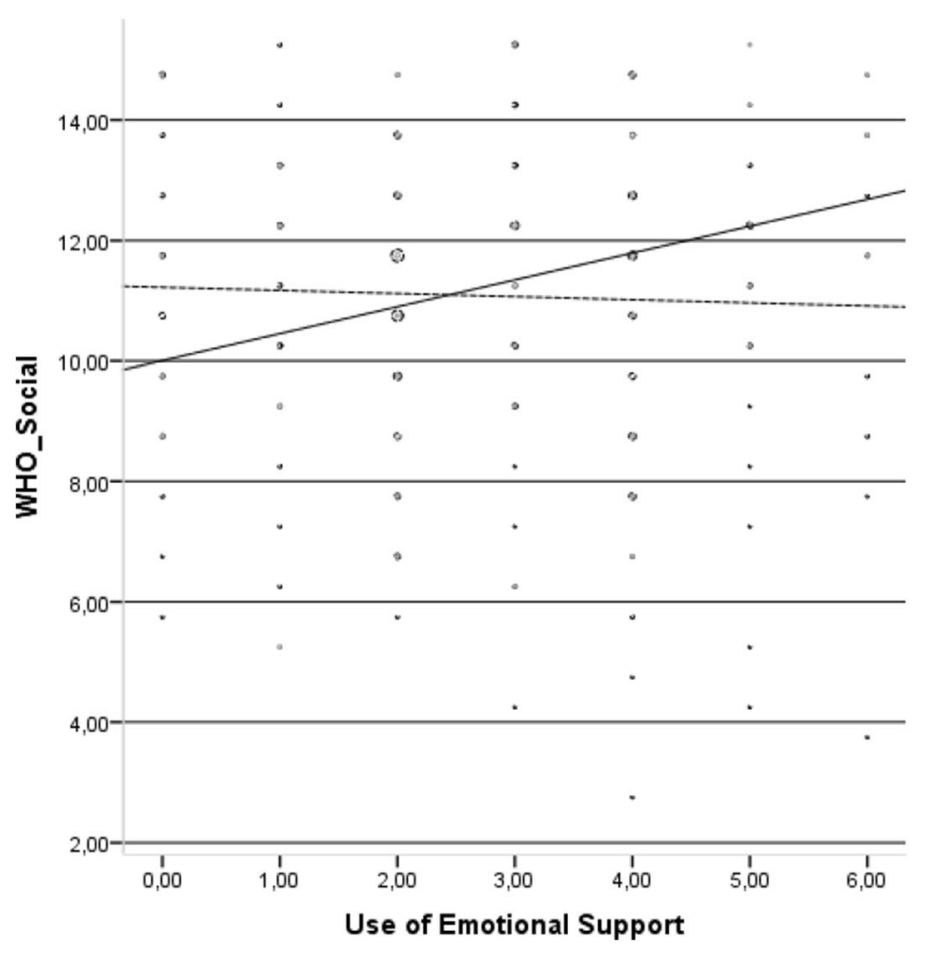

Gender Male Female Male and environmental domains among HIV-infected women can be understood rather as a derivative of a worse occupational situation and a lower level of education compared to HIVinfected men. On one hand, several authors observed the beneficial role of employment on HRQoL among PLWH, even after controlling for the severity of HIV progression (Blalock et al. 2002; Worthington and Krentz 2005). More recently,
Ruedaa et al. (2011) showed that employment status was the strongest predictor of physical and mental domain of HRQoL among PLWH and outweighed the role of other demographic factors, social support, clinical variables, and even neurocognitive functioning. It is well-known that PLWH are under constant threat of losing their employment (Samson et al. 2009), and, when they lose their jobs, they face several
Fig. 5 Relationship between positive emotion enhancement and psychological domain of health-related quality of life in the group of HIV-infected men and HIV-infected women

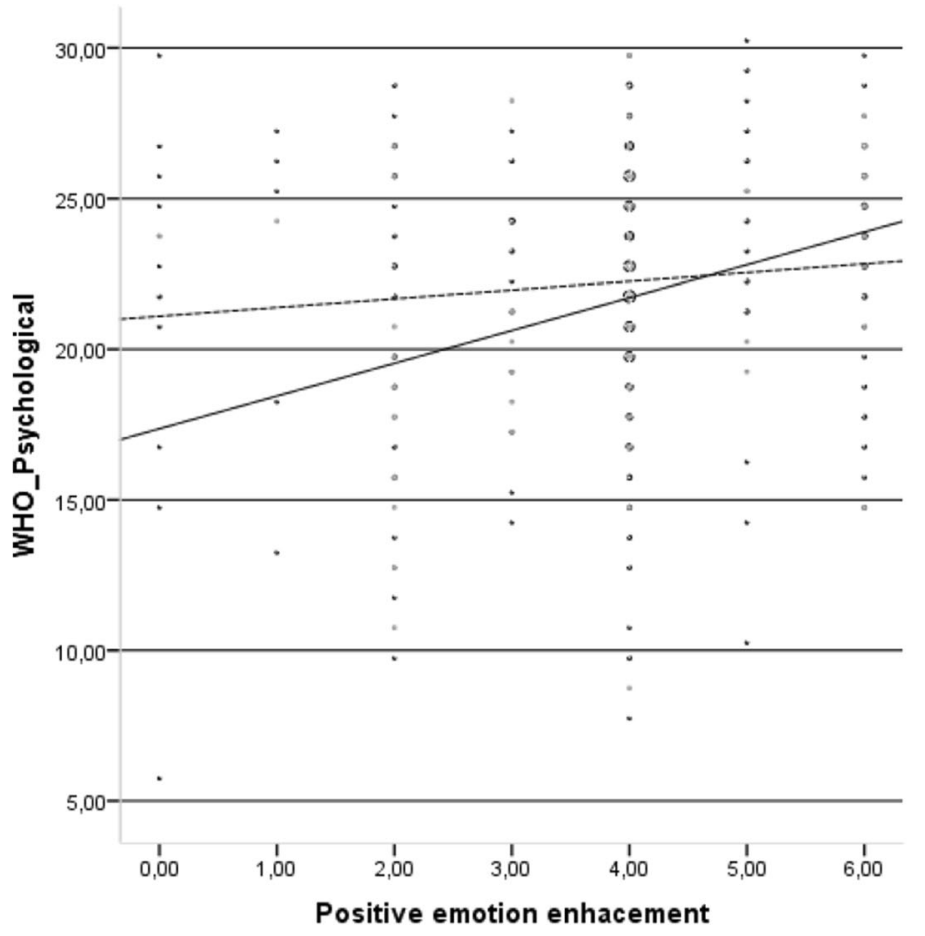

Gender 
barriers to workforce re-entry (Martin et al. 2003); this especially relates to HIV-infected women (Aziz and Smith 2011). Similarly, higher education appeared to be not only a personal resource in coping with HIV-related distress among PLWH (O'Leary et al. 2014) and also protected them from depression (Lee et al. 2014), but it was also positively related to HRQoL (da Silva et al. 2013). Conversely, lower education is significantly correlated to heightening perceived stigma, observed especially among HIV-infected women (Wagner et al. 2010).

The second hypothesis was positively verified, as several statistically significant interactions between participants' gender and coping strategies in relation to HRQoL domains were observed. Interestingly, in almost all instances of these interactions, the relationship between HRQoL and coping was statistically significant in the group of HIV-infected women, which may indicate that gender differences in HRQoL among PLWH are strictly associated with appropriate coping with HIV infection. More specifically, positive reframing was positively related to the somatic and environmental domains of HRQoL only in the group of HIV-infected women. Until now, positive reframing appeared to be positively related to different domains of QoL among PLWH in a few studies, but gender differences were not taken into account (Armon and Lichtenstein 2012; Moskowitz et al. 2009, 2012). In only one research that of Weaver et al. (2004), was it found that HIV-infected women who relied more on positive reframing were characterized by higher levels of various QoL domains as they perceived lower levels of stress in their closest environment.

Additionally, whereas the use of emotional support appeared to be negatively associated with the somatic domain of HRQoL in the group of HIV-infected men, this coping strategy was positively linked with the HRQoL social domain in the group of HIV-infected women. This specific finding was somewhat opposed to that of other studies, which showed that HIV-infected men gain more in terms of well-being from receiving emotional support compared to HIV-infected women, as the latter have difficulty in accepting this type of support due to the greater level of HIV-related stigma that they experience (Gordillo et al. 2009). On the other hand, Rzeszutek et al. (2016) observed that HIV-infected women had a higher need for support and, thus, received more support compared to HIV-infected men. This is also in accordance with other studies that pointed to a high intensity of support seeking among HIV-infected women, despite stigmatization (Jones et al. 2007). Furthermore, Kotze et al. (2013) longitudinal research found that an increase in active coping was positively related with receiving more social support among newly HIV-infected women during pregnancy which, in turn, resulted in a decrease in perceived stigma. Thus, one may hypothesize that, among HIV-infected women, appropriate coping may play a beneficial role in various aspects of social functioning, including managing HIVrelated stigma and various barriers to seeking and receiving social support (Vyavaharkar et al. 2007).

Finally, positive emotional enhancement was positively related to the psychological domain of HRQoL only in the group of HIV-infected women. An increasing number of authors highlighted the beneficial role of positive effects among PLWH in various areas of functioning (Ironson and Hayward 2008; Moskowitz et al. 2017). More specifically, positive effects were negatively related to mortality rate (Moskowitz 2003), predicted lower viral load (Wilson et al. 2016), caused slower progression of HIV infection (Ironson and Hayward 2008) and were negatively associated with depression ( $\mathrm{Li}$ et al. 2016). In terms of specific positive affect actions, interventions appeared to be successful in improving psychological functioning and adjustment among PLWH (Moskowitz et al. 2017); thus, these types of interventions should be especially tailored to HIV-infected women.

\section{Limitations}

This study is not free from limitations. Firstly, the crosssectional design of this study precludes causal interpretations. It specifically deals with understanding the relationship between HRQoL and coping strategies. Secondly, other sociodemographic (e.g., sexual orientation) or clinical variables (e.g., HIV transmission and viral load) were not controlled in this study. Finally, a significant underrepresentation of women may be observed in the study, but the gender ratio was rather typical for other studies conducted on PLWH (Bor et al. 2015).

\section{Conclusions}

The results of this study suggest that future research on the aforementioned topic should take into account the unique differences between HIV-infected men and HIV-infected women across not only socio-medical factors, but also in regard to psychosocial variables. Perhaps, more complex controlling of these differences may verify the traditional trend in the literature pointing to lower HRQoL among HIV-infected women. More specifically, it seems that HRQoL among HIV-infected women depends more on coping strategies compared to HIV-infected men; this should be taken into account in the psychological counseling of HIV-infected women.

\section{Compliance with ethical standards}

Disclosure of potential conflicts of interest The author declares that he has no conflict of interest. 
Research involving human participants and/or animals All procedures performed in studies involving human participants were in accordance with the ethical standards of the institutional and/or national research committee and with the 1964 Helsinki declaration and its later amendments or comparable ethical standards.

Informed consent Informed consent was obtained from all individual participants included in the study.

Open Access This article is distributed under the terms of the Creative Commons Attribution 4.0 International License (http:// creativecommons.org/licenses/by/4.0/), which permits unrestricted use, distribution, and reproduction in any medium, provided you give appropriate credit to the original author(s) and the source, provide a link to the Creative Commons license, and indicate if changes were made.

\section{References}

Adewuya A, Afolabi M, Ola B, Ogundele O, Ajibare A, Oladipo B, Fakande I (2009) Post-traumatic stress disorder (PTSD) after stigma related events in HIV infected individuals in Nigeria. Soc Psychiatry Psychiatr Epidemiol 44(9):761-766. https://doi.org/10.1007/ s00127-009-0493-7

Armon C, Lichtenstein K (2012) The associations among coping, nadir CD4+ T-cell count, and non-HIV-related variables with healthrelated quality of life among an ambulatory HIV-positive patient population. Qual Life Res 21(6):993-1003. https://doi.org/10. 1007/s11136-011-0017-2

Ashton E, Vosvick M, Chesney M (2005) Social support and maladaptive coping as predictors of the change in physical health symptoms among persons living with HIV/AIDS. AIDS Patient Care STDs 19(9):587-598. https://doi.org/10.1089/apc.2005.19.587

Aziz M, Smith K (2011) Challenges and successes in linking HIVinfected women to care in the United States. Clin Infect Dis 52(suppl_2):231-237. https://doi.org/10.1093/cid/ciq047

Blalock A, McDaniel J, Farber E (2002) Effect of employment on quality of life and psychological functioning in patients with HIV/AIDS. Psychosomatics 43(5):400-404. https://doi.org/10.1176/appi.psy. 43.5.400

Bogart L, Wagner G, Galvan F, Landrine H, Klein D (2011) Perceived discrimination and mental health symptoms among black men with HIV. Cultur Divers Ethnic Minor Psychol 17(3):295-302. https:// doi.org/10.1037/a0024056

Bor J, Rosen S, Chimbindi N, Haber N, Herbst K, Mutevedzi T, Tanser F, Pillay D, Bärnighausen T (2015) Mass HIV treatment and sex disparities in life expectancy: demographic surveillance in rural south Africa. PLOS Med 24:12-21

Bucciardini R, Pugliese K, Weimer L, Digregorio M, Fragola V, Mancini M (2014) Relationship between health-related quality of life measures and high HIV viral load in HIV-infected triple-classexperienced patients. HIV Clin Trials 15(4):176-183. https://doi. org/10.1310/het1504-176

Burgoyne R, Saunders D (2001) Quality of life among urban Canadian HIV/AIDS clinic outpatients. Int J STD AIDS 12(8):505-512. https://doi.org/10.1328/a03564056

Campbell C, Nair S, Maimane MAIDS (2006) Stigma, sexual moralities and the policing of women and youth in South Africa. Fem Rev 83(1):132-138. http://www.jstor.org/stable/3874387. https://doi. org/10.1057/palgrave.fr.9400285

Campsmith M, Nakashima A, Davidson A (2003) Self-reported healthrelated quality of life in persons with HIV infection: results from a multi-site interview project. Health Qual Life Outcomes 1(1):12. https://doi.org/10.1186/1477-7525-1-12
Carvalhal A (2010) Are women a different group of HIV-infected individuals? Arch Womens Ment Health 13(3):181-183. https://doi.org/ 10.1007/s00737-010-0167-1

Carver C, Scheier M (1997) Situational coping and coping dispositions in a stressful transaction. J Pers Soc Psychol 66:184-195

Chandra P, Satyanarayana V, Satishchandra P, Satish K, Kumar M (2009) Do men and women with HIV differ in their quality of life? A study from South India. AIDS Behav 13(1):110-117. https://doi.org/10. 1007/s10461-008-9434-9

Chida Y, Vedhara K (2009) Adverse psychosocial factors predict poorer prognosis in HIV disease: a meta-analytic review of prospective investigations. Brain Behav Immun 23(4):434-445. https://doi.org/ 10.1016/j.bbi.2009.01.013

Collazos J, Asensi V, Carto J (2007) Sex differences in the clinical, immunological and virological parameters of HIV-infected patients treated with HAART. AIDS 21(7):835-843. https://doi.org/10. 1097/QAD.0b013e3280b0774a

da Silva J, Bunn K, Bertoni R, Neves O, Traebert J (2013) Quality of life of people living with HIV. AIDS Care 25(1):71-76. https://doi.org/ $10.1080 / 09540121.2012 .686594$

Darlington R, Hayes A (2017) Regression analysis and linear models: concepts, application, and implementation. The Guilford Press, New York

Deeks S, Lewin S, Havlir D (2013) The end of AIDS: HIV infection as a chronic disease. Lancet 382(9903):1525-1533. https://doi.org/10. 1016/S0140-6736(13)61809-7

Degroote S, Vogelaers D, Vandijck D (2014) What determines healthrelated quality of life among people living with HIV: an updated review of the literature. Arch Public Health 72(1):40. https://doi. org/10.1186/2049-3258-72-40

Emuren L, Welles S, Evans A, Polansky M, Okulicz J, Macalino G, Agan B (2017) Health-related quality of life among military HIV patients on antiretroviral therapy. PLoS One 12(6):e0178953. https://doi.org/ 10.1371/journal.pone.0178953

Endler N, Parker J, Summerfeldt L (1998) Coping with health problems: developing a reliable and valid multidimensional measure. Psychol Assess 10(3):195-205. https://doi.org/10.1037/1040-3590.10.3.195

Geary C, Parker W, Rogers S, Haney E, Njihia C, Haile A (2014) Gender differences in HIV disclosure, stigma, and perceptions of health. AIDS Care 26(11):1419-1425. https://doi.org/10.1080/09540121. 2014.921278

Gielen A, McDonnell K, Campo P, Faden R (2001) Quality of life among women living with HIV: the importance violence, social support, and self-care behaviors. Soc Sci Med 52(2):315-322. https://doi. org/10.1016/S0277-9536(00)00135-0

Gordillo V, Fekete E, Platteau T, Antoni M, Schneiderman N, Nostlinger C (2009) Emotional support and gender in people living with HIV: effects on psychological well-being. J Behav Med 32(6):523-531. https://doi.org/10.1007/s10865-009-9222-7

Gore-Felton C, Koopman C, Turner-Cobb J, Duran R, Israelski D, Spiegel D (2002) The influence of social support, coping and mood on sexual risk behavior among HIV-positive men and women. J Health Psychol 7(6):713-722. https://doi.org/10.1177/ 1359105302007006874

Griswold G, Evans S, Spielman L, Fishman B (2005) Coping strategies of HIV patients with peripheral neuropathy. AIDS Care 17(6):711720. https://doi.org/10.1080/09540120412331336715

Herrmann S, McKinnon E, Hyland N, Lalanne C, Mallal S, Nolan D, Chassany O, Duracinsky M (2013) HIV-related stigma and physical symptoms have a persistent influence on health-related quality of life in Australians with HIV infection. Health Qual Life Outcomes 11(1):56. https://doi.org/10.1186/1477-7525-11-56

IBM Corp. Released. IBM SPSS Statistics for Windows. Version 24 (2016) Armonk. IBM Corp, NY

Ironson G, Hayward H (2008) Do positive psychosocial factors predict disease progression in HIV-1? A review of the evidence. Psychosom 
Med 70(5):546-554. https://doi.org/10.1097/PSY. $0 \mathrm{~b} 013 \mathrm{e} 318177216 \mathrm{c}$

Jia H, Uphold C, Wu S, Reid K, Findley K, Duncan P (2004) Healthrelated quality of life among men with HIV infection: effects of social support, coping, and depression. IDS Patient Care STDs 18(10):594-603. https://doi.org/10.1089/apc.2004.18.594

Joint United Nations Programme on HIV/AIDS (UNAIDS) Report (2017). http://www.unaids.org/sites/default/files/media_asset/ GlobalAIDSupdate_2017en.pdf

Jones D, McPherson-Baker S, Lydston D, Camille J, Brondolo E, Tobin J, Weiss S (2007) Efficacy of a group medication adherence intervention among HIV positive women: the SMART/EST women's project. AIDS Behav 11(1):79-86. https://doi.org/10.1007/s10461-0069165-8

Kotze M, Visser M, Makin J, Sikkema K, Forsyth B (2013) Psychosocial factors associated with coping among women recently diagnosed HIV-positive during pregnancy. AIDS Behav 17(2):498-507. https://doi.org/10.1007/s10461-012-0379-7

Lee M, Nezu A, Nezu C (2014) Positive and negative religious coping, depressive symptoms, and quality of life in people with HIV. J Behav Med 37(5):921-930. https://doi.org/10.1007/s10865-0149552-y

Li J, Mo P, Wu A, Lau J (2016) Roles of self-stigma, social support, and positive and negative affects as determinants of depressive symptoms among HIV infected men who have sex with men in China. AIDS Behav 21(1):261-273. https://doi.org/10.1007/s10461-0161321-1

Liu C, Ostrow D, Detels R, Hu Z, Johnson L, Kingsley L, Jacobson L (2006) Impacts of HIV infection and HAART use on quality of life. Qual Life Res 15(6):941-949. https://doi.org/10.1007/s11136-0055913-X

Machtinger E, Wilson T, Haberer J, Weiss D (2012) Psychological trauma and PTSD in HIV-positive women: a meta-analysis. AIDS Behav 16(8):2091-2100. https://doi.org/10.1007/s10461-011-0127-4

Martin D, Brooks R, Ortiz D, Veniegas R (2003) Perceived employment barriers and their relation to workforce-entry intent among people with HIV/AIDS. J Occup Health Psychol 8(3):181-194. https://doi. org/10.1037/1076-8998.8.3.181

McDonnell K, Gielen A, Wu A, Campo P, Faden R (2000) Measuring health related quality of life among women living with HIV. Qual Life Res 9(8):931-940. https://doi.org/10.1023/A:1008909919456.

Miners A, Phillips A, Kreif N, Rodger A, Speakman A, Fisher M, Anderson J, Collins S, Hart G, Sherr L, Lampe F (2014) Healthrelated quality-of-life of people with HIV in the era of combination antiretroviral treatment: a cross-sectional comparison with the general population. Lancet HIV 1(1):e32-e40. https://doi.org/10.1016/ S2352-3018(14)70018-9

Mitchell M, Nguyen T, Isenberg S, Maragh-Bass A, Keruly J, Knowlton A (2017) Psychosocial and service use correlates of health-related quality of life among a vulnerable population living with HIV/ AIDS. AIDS Behav 21(6):1580-1587. https://doi.org/10.1007/ s10461-016-1589-1

Moskowitz J (2003) Positive affect predicts lower risk of AIDS mortality. Psychosom Med 65(4):620-626. https://doi.org/10.1097/01.PSY. 0000073873.74829 .23

Moskowitz J, Hult J, Bussolari C, Acree M (2009) What works in coping with HIV? A meta-analysis with implications for coping with serious illness. Psychol Bull 135(1):121-141. https://doi.org/10.1037/ a0014210

Moskowitz J, Hult J, Duncan L, Cohn M, Maurer S, Bussolari C, Acree M (2012) A positive affect intervention for people experiencing health-related stress: development and non-randomized pilot test. J Health Psychol 17(5):676-692. https://doi.org/10.1177/ 1359105311425275

Moskowitz J, Carrico A, Duncan L, Cohn M, Cheung E, Batchelder A (2017) Randomized controlled trial of a positive affect intervention for people newly diagnosed with HIV. J Consult Clin Psychol 85(5): 409-423. https://doi.org/10.1037/ccp0000188

Mrus J, Williams P, Tsevat J, Cohn S, Wu A (2005) Gender differences in health-related quality of life in patients with HIV/AIDS. Qual Life Res 14(2):479-491. https://doi.org/10.1007/s11136-004-4693-Z

Nicastri E, Leone S, Angeletti C, Palmesano L, Sarmati L, Chiesi A et al (2007) Sex issues in HIV-1-infected persons during highly active antiretroviral therapy: a systematic review. J Antimicrob Chemother 60(4):724-732. https://doi.org/10.1093/jac/dkm302

Nolen-Hoeksema S, Wisco BE, Lyubomirsky S (2008) Rethinking rumination. Perspect Psychol Sci 3(5):400-424. https://doi.org/10.1111/ j.1745-6924.2008.00088.x

O'Leary A, Jemmott J, Stevens R et al (2014) Optimism and education buffer the effects of syndemic conditions on HIV status among African American men who have sex with men. AIDS Behav 18(11):2080-2088. https://doi.org/10.1007/s10461-014-0708-0

Pantalone D, Hessler D, Simoni J (2010) Mental health pathways from interpersonal violence to health-related outcomes in HIV-positive sexual minority men. J Consult Clin Psychol 78(3):387-397. https://doi.org/10.1037/a0019307

Peltzer K, Phaswana-Mafuya N (2008) Health-related quality of life in a sample of HIV-infected South Africans. Afr J AIDS Res 7(2):209 218. https://doi.org/10.2989/AJAR.2008.7.2.6.523

Pence B, Thielman N, Whetten K, Ostermann J, Kumar V, Mugavero M (2008) Coping strategies and patterns of alcohol and drug use among HIV-infected patients in the Unites States southeast. AIDS Patient Care STDs 22(11):869-777. https://doi.org/10.1089/apc. 2008.0022

Penniman T, Taylor S, Bird C, Beckman R, Collins R, Cunningham W (2007) The associations of gender, sexual identity and competing needs with healthcare utilization among people with HIV/AIDS. J Natl Med Assoc 99:419-427

Ruedaa S, Raboud J, Mustard C, Bayoumi A, Lavis J, Rourke S (2011) Employment status is associated with both physical and mental health quality of life in people living with HIV. AIDS Care 23(4): 435-443. https://doi.org/10.1080/09540121.2010.507952

Ruiz-Perez I, Baño R, Ruz A, Jimenez A, Prados M, Liaño P, Rico P et al (2005) Health-related quality of life of patients with HIV: impact of sociodemographic, clinical and psychosocial factors. Qual Life Res 14(5):1301-1310. https://doi.org/10.1007/s11136-004-4715-x

Ruiz-Perez I, Olry A, del Castilloc L, Bano J, Ruz M, Jimeneze A (2009) No differences in quality of life between men and women undergoing HIV antiretroviral treatment. Impact of demographic, clinical and psychosocial factors. AIDS Care 21(8):943-952. https://doi. org/10.1080/09540120802612840

Rzeszutek M, Oniszczenko W, Firlag-Burkacka E (2012) Temperament traits, coping style and trauma symptoms in HIV+ men and women. AIDS Care 24(9):1150-1154. https://doi.org/10.1080/09540121. 2012.687819

Rzeszutek M, Oniszczenko W, Żebrowska M, Firlag-Burkacka EHIV (2015) Infection duration, social support and the level of trauma symptoms in a sample of HIV-positive Polish individuals. AIDS Care 27(3):363-369. https://doi.org/10.1080/09540121.2014. 963018

Rzeszutek M, Oniszczenko W, Firlag-Burkacka E (2016) Gender differences in posttraumatic stress symptoms and social support in a sample of HIV-positive individuals. Women Health 57(7):792-803. https://doi.org/10.1080/03630242.2016.1206057

Samji H, Cescon A, Hogg R, Modur S, Althoff K (2013) Closing the gap: increases in life expectancy among treated HIV-positive individuals in the United States and Canada. PLoS One 18:144-156

Samson A, Lavigne R, MacPherson P (2009) Self-fulfilment despite barriers: volunteer work of people living with HIV. AIDS Care 21(11): 1425-1431. https://doi.org/10.1080/09540120902814403

Skinner E, Edge K, Altman J, Sherwood H (2003) Searching for the structure of coping: a review and critique of category systems for 
classifying ways of coping. Psychol Bull 129(2):216-269. https:// doi.org/10.1037/0033-2909.129.2.216

Solomon S, Venkatesh K, Brown L, Verma P, Cecelia A, Daly C, Mahendra V, Cheng N, Kumarasamy N, Mayer K (2008) Genderrelated differences in quality of life domains of persons living with HIV/AIDS in South India in the era prior to greater access to antiretroviral therapy. AIDS Patient Care STDs 22(12):999-1005. https://doi.org/10.1089/apc.2008.0040

Song B, Yan C, Lin Y, Fuxiang W, Wang L (2016) Health-related quality of life in HIV-infected men who have sex with men in China: a cross-sectional study. Med Sci Monit 22:2859-2870. https://doi. org/10.12659/MSM.897017

Tarakeshwar N, Pearce M, Sikkema K (2005) Development and implementation of a spiritual coping group intervention for adults living with HIV/AIDS: a pilot study. Ment Health Relig Cult 8(3):179190. https://doi.org/10.1080/13694670500138908

Treynor W, Gonzalez R, Nolen-Hoeksema S (2003) Rumination reconsidered: a psychometric analysis. Cogn Ther Res 27(3):247259. https://doi.org/10.1023/A:1023910315561

Vervoort S, Grypdonck M, de Grauwe A, Hoepelman A, Borleffs J (2009) Adherence to HAART: processes explaining adherence behaviour in acceptors and non-acceptors. AIDS Care 21(4):431-438. https://doi.org/10.1080/09540120802290381

Vo Q, Hoffman S, Nash D, El-Sadr W, Tymejczyk O, Gadisa T, Melaku Z, Kulkarni S, Remien R, Elul B (2016) Gender differences and psychosocial factors associated with quality of life among ART initiators in Oromia, Ethiopia. AIDS Behav 20(8):1682-1691. https://doi.org/10.1007/s10461-016-1396-8

Vosvick M, Gore-Felton C, Koopman C, Thoresen C, Krumboltz J, Spiegel D (2002) Maladaptive coping strategies in relation to quality of life among HIV adults. AIDS Behav 6(1):97-106. https://doi.org/ 10.1023/A:1014584730432

Vosvick M, Martin L, Smith N, Jenkins S (2010) Gender differences in HIV-related coping and depression. AIDS Behav 14(2):390-400. https://doi.org/10.1007/s10461-008-9490-1

Vyavaharkar M, Moneyham L, Tavakoli A, Phillips K, Murdaugh C, Jackson K, Meding G (2007) Social support, coping, and medication adherence among HIV-positive women with depression living in rural areas of the southeastern United States. AIDS Patient Care STDs 21(9):667-680. https://doi.org/10.1089/apc.2006.0131

Wagner A, Hart T, Mohammed S, Ivanova E, Wong J, Loutfy M (2010) Correlates of HIV stigma in HIV-positive women. Arch Womens Ment Health 13(3):207-214. https://doi.org/10.1007/s00737-010$0158-2$

Weaver K, Antoni M, Lechner S, Duran R, Penedo F, Fernandez I, Ironson G, Schneiderman N (2004) Perceived stress mediates the effects of coping on the quality of life of HIV-positive women on highly active antiretroviral therapy. AIDS Behav 8(2):175-183. https://doi.org/10.1023/B:AIBE.0000030248.52063.11

WHOQOL Group (1995) WHOQOL group, the World Health Organization quality of life assessment: position paper from the World Health Organization. Soc Sci Med 41:1403-1409

Wilson T, Weedon J, Cohen M, Golub E, Milam J, Young M, Fredrickson B (2016) Positive affect and its association with viral control among women with HIV infection. Health Psychol 36(1):91-100. https:// doi.org/10.1037/hea0000382

Worthington C, Krentz H (2005) Socio-economic factors and healthrelated quality of life in adults living with HIV. Int J STD AIDS 16(9):60-614. https://doi.org/10.1258/0956462054944408 